\title{
Changes in Human Resources Management (Hrm) in Transition From Past Towards Today's Information Society
}

\author{
Hasan AYDOĞDU ${ }^{1}$ \\ Ruhi BAĞÇIVAN ${ }^{2}$
}

\begin{abstract}
Human Resources Management (HRM), which is based on human as a dynamic element of working life, has undergone a rapid transformation. In the past, practices known as employee record keeping, social service duties, personnel management, and industrial relations have become a phenomenon of HRM along with the processes of change and transformation. Today, HRM has become a part of strategic management. The aim of this study is to reveal the changes that human resources management has undergone since its emergence, and to shed light on its future. In this respect, the applications and transformations of HRM from agricultural society to information society are investigated, based on the results of this theoretical research and the problems encountered with information society transformations, the future of human resources management is projected.
\end{abstract}

Keywords: Personnel Management, Human Resources Management (HRM), Strategic Human Resources Management (SHRM), Change, Information Society.

\footnotetext{
${ }^{1}$ Assist. Prof., İstanbul Aydın University, School of Applied Sciences, Department of Management Information Systems, hasanaydogdu@aydin.edu.tr

${ }^{2} \mathrm{PhD}$ Student, İstanbul University, ruhibagcivan@yahoo.com

Doi Num: 10.17932/IAU.FCPE.2015.010/fcpe_v06i1003
} 


\section{Geçmişten Günümüze Bilgi Toplumuna Geçişte İnsan Kaynakları Yönetiminde Yaşanan Değişim}

\section{$\ddot{O Z Z}$}

Çalışma hayatının dinamik bir unsuru olarak insanı temel alan insan kaynakları yönetimi (İKY) hızlı bir dönüşüm yaşamıştır. Geçmişte çalışanların kayıtlarını tutma, sosyal hizmet görevi, personel yönetimi ve endüstri ilişkileri olarak bilinen uygulamalar, değişim ve dönüşüm süreçleriyle birlikte İKY olgusuna dönüşmüştür. Günümüzde ise İKY, stratejik yönetimin bir parçası haline gelmiştir. Bu çalışmanın amacı, insan kaynakları yönetiminin ortaya çıkışından itibaren günümüze kadar geçirdiği değişimleri ortaya koymak ve geleceğine 1şık tutmaktır. $\mathrm{Bu}$ açıdan, İKY'nin tarım toplumundan, bilgi toplumuna kadar uygulamaları ve yaşadığı dönüşümler araştırılmakta; bu kuramsal araştırmanın sonuçları ve bilgi toplumu dönüşümleriyle karşılaşılan sorunlardan hareketle, insan kaynakları yönetiminin geleceğine ilişkin projeksiyon yapılmaktadır.

Anahtar Kelimeler: Personel Yönetimi, Insan Kaynakları Yönetimi (IKKY), Stratejik Insan Kaynakları Yönetimi, Değişim, Bilgi Toplumu.

\section{INTRODUCTION}

Since the last quarter of the 20th century, our world has come under the influence of the phenomenon of change. Change radically changes all the dynamics of organizations. The basic resource that gives life to organizations is human. Therefore, every process related to change and development affects the person in the working life in some way. Human Resource Management (HRM) is the branch of science responsible for improving the productivity and quality of the working life of the human. It is not a coincidence that the idea of human resources management and the processes of change and development are simultaneous. On the contrary, because the target group of change and development is human, human resources management is placed at the center of change and development.

In this article, the emergence of the practices that started with the record keeping process for the employee in business life, the transformation of the social service task, the emergence of the phenomenon of personnel management, the inclusion of trade union movement and industrial relations in the process, the rediscovery of human resources and the human 
resources management process, the expansion of the concept and scope of human resources, taking it to strategic dimension, the new dimensions that information society processes have brought to human resource management and, are likely to bring in the future, are all investigated within corporate research methods. It is assumed that the study will shed some theoretical light on the work to be done about the history and future of human resources.

\section{HISTORICAL PROGRESS OF HUMAN RESOURCES MANAGEMENT}

\section{Pioneers of Human Resources Management in Agricultural Societies}

It is a general approach to take the beginning of the sciences to the early ages of history. This approach also applies to personnel management; because it is possible to base management thought and personnel management on human history. However, management science, which is a systematic collection of information about management and organizations, is the result of the 20th century (Baransel, 1979:5).

Management is the sum of efforts to ensure the unity of purpose of people, and to lead them towards this goal. In other words, the sum of the activities of achieving the goals or making others work through others constitutes the management process (Tosun, 1990:161). In every organization, where people come together to produce work, there are both human-specific relationships and management relationships. In general, all employees in an organization constitute human resources (Aktan, 2003:227). It can be proposed that human resources management is also in every place where people and organizations exist (Akdemir et al., 2001:15). Early in history, it is possible to find examples of practices that can be associated with human resources. Hunting, fishing, leadership strength, endurance, talent, loyalty to the clan, age and gender discrimination in doing business, and the effectiveness of traditions achieved together in the Paleotic and early Neolithic periods can be evaluated in this context. Likewise, in the late Neolithic, Bronze and Iron Age, apprenticeship, father-to-son occupation, simple record keeping and payments can be seen as early examples of human resources management (Bass, 1994:3-5).

More concrete examples include the management and organization in the construction of pyramids in Ancient Egypt, the contributions of Socrates 
and Aristotle in ancient Greece to the management idea in terms of universality and science (Yozgat, 1992:4), also military organizations in Roman civilization. More recently, Adam Smith's mention of the division of labour in his 1776 book "The Wealth of Nations" (Türkel, 1998:67-70) forms the building blocks for the emergence of the idea of management as well as the idea of human resources management.

By using the sources known in the history of management, we can say that there is a human resources management function on the basis of "record keeping" (Yüksel, 2000:10) in the agricultural society and in the periods when small workshop-style enterprises are common and that they are involved in organizations as such. It is the business owners who take on the task of keeping records in small businesses. Sometimes one of the employees, or a senior employee, is tasked with keeping records. As the number of employees gradually increased, an accountant who was also concerned with wages became involved in organizations tasked with keeping records of employees.

\section{Pre-Industrial Revolution and Social Worker}

The Industrial Revolution, which started in England in the middle of the 18th century and then spread to Europe and the whole World (Köksal, 2005:7), led to many changes in business and social life. The importance of personnel issues is due to this change. The change has revealed the first examples of HRM practices in today's sense. In this respect: the work of Adam Smith in 1776 to simplify things; the first strike of the Philadelphia printing workers in 1786 for a wage increase; the implementation of the first profit-sharing scheme in America in 1794 and the adoption of laws regulating work life; the developments following the opening of the London Industrial Exhibition in 1850 are examples of pioneering formations in HRM (Baysal, 1993: 59).

The age of mechanization (1870s), which formed the early stages of the industrial revolution, led to the growth of workshops and small businesses and the emergence of factories. Thus, there has been a transformation from agricultural labor to factory labor. During this period human resources management functions such as hiring, dismissal and keeping records were carried out by line managers. 
In parallel with the growth of enterprises and the growth of factories in the same period, organizational problems arising from growth also began to gain importance (Ülgen, 1993:11). The workers' search for unity intensified due to extraordinarily poor working conditions during this period. Unionism, as a result of these pursuits, first appeared in Britain and spread to other countries as well (Pannekoek, 2006).

With these developments, some socially conscious employers, seeing the difficulty of having a close personal relationship with a large number of their employees in their overgrown factories, began to implement the "social worker" idea proposed by the American Institute of Social Services in the United States (USA) in 1889. Employment of social workers, who may be considered the first specialized human resources officer, became widespread in the early industrial period (Demirkaya, 2004).

Social workers have a moderator role between managers and employees. These officers on one hand helped to solve the problems such as employees' health, housing, finance etc., they also represented the value that management gave them. The practice of social worker is accepted by both employees and employers and has brought professionals who perform human resources management functions of the period into the business life. Although the profession did not initially have a set criteria, the first social workers' conference was held in America in 1893, the first Social Workers' Association was established in England in 1913, and the profession of social workers' expertise entered the institutionalization process (Baysal, 1993:59).

\section{Birth of Personnel Management}

The second phase of the Industrial Revolution and the developments in the field of management and organization have taken the human resources management function to new dimensions beyond social worker practices. The scientific management movement that emerged towards the end of the 19th century contributed to the professional development of personnel management (Bingöl, 1997:10). Frederick W. Taylor, one of the pioneers of this idea summarized the work he had done until then with his work "Scientific Management" in 1911 (Eren, 1991:16). By using concepts such as division of labour into departments, standardization, work-employee compliance, selection of suitable employees, training, incentive pay 
systems (Koçel, 1989:122), this has revealed the need for professionals to increase employee productivity. As a result of this need, for the first time in 1912, the "personnel department" took part in organizations as a separate department (Bingöl, 1997:12). The use of tests for the first time in the selection of personnel for the U.S. Army in World War I conditions was a development that revealed the importance of organizing the personnel department as a separate department. The publication of the book "personnel administration" in 1920 was an important step that contributed to the development of personnel management (Baysal, 1993:60). With these developments, the concept of "personnel management" has taken its place in the management literature.

\section{HUMAN RELATIONS PERIOD AND INDUSTRIAL RELATIONS PROCESS}

In 1920s and 1930s, Harvard University researchers Elton Mayo and F.J. Roethlisberger's studies and experiments at the Hawtorne plant of the Western Electric Company revealed the view that "organization is a social system and human beings are the most important factor in this system" (Davis, 1988:11). This idea, which emerged as a result of Hawtorne studies, was initially "human relations approach", then "management of human resources", and today it has been continued as "organizational behavior".

These studies prioritized perception, attitudes, motivation, leadership, change and development in the organization (Koçel, 1989:81), emphasizing the contribution of behavior and organizational environment to individual productivity, so personnel management function has given new dimensions moving it to "working relations" position. In addition, low wages, long working hours, social explosions caused by the abuse of women and child laborers forced the states to intervene in the industrial relations system (Köksal, 2005:8). Thus, "industrial relations", which initially focused on labour problems (Kauffman, 2001:7), along with all the problems related to trade unionism and trade unions that had been founded before, became involved in the activities of the personnel departments.

The fact that productivity and quality are indispensable brought about by the developments in the Second World War and its aftermath has brought to the fore the idea of taking maximum efficiency from human resources, too. In addition, since productivity and quality are associated with training, 
the phenomenon of "employee-employee training" is also included in the personnel departments' area of responsibility.

As a result of these developments in the 1940s in the USA, the concept of "personnel manager", which has expertise in education, employment, performance evaluation, wage management, employee-employer relations, and insurance, has started to be used. The 1940s also witnessed the approach of human relations, which, after the classical understanding of management, centered on human beings, was expressed through concepts such as organizational rationality and open door policy. In all these progresses, it is necessary to take into account the positive contributions of the trade union movement. With the same developments, in 1946 the name of the British Institute of Labour Management (ILM) was changed to Institute of Personnel Management (IPM) (Baysal, 1993:60). With these and similar developments, it has become common for personnel management or personnel management- industrial relations professionals to take functional roles in the organizations.

Historically, the title and duty of the personnel department manager, who first emerged as a record-keeping clerical officer, has changed in accordance with developments over time. In this sense, there have been developments regarding the position of senior manager in charge of establishing systems related to the productivity of the employee, from overseer carrying out personnel affairs to lower level manager dealing with the daily problems of the employees, from mid-level manager developing relationships with the employees (Palmer and Winters, 1993:23). These developments are important milestones on the road to Human Resource Management in today's understanding.

\section{TRANSFORMATION TO HUMAN RESOURCES MANAGEMENT}

\section{Rising of Human Resources Management}

As the development of human resources management is examined historically, even though until the 1980s "personnel management", "personnel management and industrial relations" and other concepts have been widely used, it has also been seen that from the beginning of the 1950s there has been quests of new approaches (Baysal: 1993:64). 
In this sense, since the late 1950s, some industrial relations and economic experts such as Myers and Harbison began to use the phrase "human resource" in their studies on labor (Özkaplan and Selamoğlu, 2005:3).

The 1960s, when modern organizational theories began to emerge, witnessed the transformation of the process of personnel management and industrial relations. Within the framework of the "system approach", which is a manifestation of these theories, individual-organization fit, organization-environment fit and the ability to change have been seen as the condition of success.

In order to achieve this fit and transform change into success, the search for full use of human resource potential has arisen. These pursuits have paved the way for the end of traditional personnel management. It is possible to say that a human-oriented approach was seen in all the works written at that time. As a result of this approach that takes people to the center, "human resources management", which is a more comprehensive concept than personnel management, has been introduced (Akyüz, 2001:55). In the same period (1960), Human Resources Management Magazine came into publication in the United States as a movement supporting the transformation of human resources management. Some other developments that contribute to the transformation from personnel management to human resources management are also summarized:

* Achievements in Japan with the contribution of quality control philosophy since the 1960s,

* The enactment of the industrial Education Act in the UK in 1964 and the view of institutional training and development as an integral part of human resources management (Lee and Stead, 1998:299),

* Again, ethics, moral values, participatory management, industrial democracy and the quality of working life have gained importance since the middle of 1960 and employers' social responsibilities have been brought to the agenda (Woods, 1997: 392),

* Rediscovery of human from the 1980s,

* The need to look at human facts comprehensively, 
* Entering a period of productivity and development and starting to focus on human productivity criteria,

* Increase in thoughts that mere personnel affairs or industrial relations are insufficient to ensure the efficiency of human resources.

With these developments, personnel management has transformed into a structure that provides added value to the organization by showing a great change; as a result, the concept of human resources has been adopted both in the academic field and in practice (Selamoğlu, 1998:571). The concept of human resources management, which is a more comprehensive concept than personnel management, has also taken place in the field of education. These developments in the direction of transformation into human resources management have also been reflected in the field of professionalization and education of the profession. In this sense, the first human resources management course was opened at Harvard Business School in 1981. All these developments have had very positive results for the professional staff. At first, human resources management has become the focus of attention as an exciting and dynamic profession.

The new understanding of human resources management has been met with excitement in all over the world. Businesses began to establish human resources departments as if they were competing with each other. It can be argued that these departments actually assume and perform human resources functions. In the beginning, the conversion to human resources was usually a signage change. "Director of Personnel", "Director of Personnel and Industry Relations" etc. the signs were removed and replaced with a "Human Resources Manager" sign. This situation is far from reflecting a meaningful transformation. In order to be able to talk about a real transformation of human resources management, a structure in accordance with human resources philosophy must be realized. It has been suggested that an organization capable of performing such a structuring should be able to answer "yes" to most of the following questions (Akdemir, 1999:358-359). These questions are:

* Is the title of human resources manager one of the highest titles after the general manager? 
* Does the human resources manager depend directly on the top manager?

* Is the human resources manager at the highest level in the wage rankings according to its precedents?

* Is human resources general agenda item in senior management meetings?

* Are human resources employees more qualified than other departments?

* Are human resources taken into account when making strategic decisions?

* Is the human resources market closely monitored?

* Is the contribution to the organization first, then the wages are evaluated in hiring?

* Is it understood that not only hiring the best personnel, but also investing in best personnel in order to keep them as best is vital?

* Is the education and development budget higher than the market?

* Are human resources well known, their weaknesses are strengthened and their strengths are fully encouraged?

* Do supervisors take time and think about how to develop their personnel at all levels going forward?

* Is the plan ready to replace the departed person immediately?

* Is human resource not an expense (passive) element, but an asset (active)?

An organization that can say "yes" to most of these questions means that it understands the philosophy of human resources management and succeeds in organizational change. Otherwise, the change will only be a sign change. However, in our opinion, even a construction that started with a sign exchange at the beginning should be considered a positive step in terms of change. 


\section{The Effects of The Perception of Human as a Strategic Resource on Human Resources Management}

Although the development aspect of human resources today is oriented towards strategic human resources management (Wimbush, 2005:463), it is not too old to consider human resources as a strategic resource. It should be met as natural. In 1965, strategic thinking, which laid the foundation for modern organizational theories, gained its first written document with Ansoff's book "Corporate Strategy" (Beagrie, 2004:22). Quality has been more of a role for organizations to look at human resources as strategic resources. The human resources of the organization are important in order to take part in Total Quality Management (TQM) understanding in organizations, to establish systems related to total quality, to share vision, mission and values, to implement unconditional customer satisfaction philosophy. More importantly, the satisfaction of external customers is possible to a large extent and primarily through the satisfaction of internal customers. This has given strategic importance to employees and therefore to human resources management. With these approaches, human resources management has entered a period of high performance since the late 1970s. In addition to financial motivations, that provides psychological satisfaction to employees mental motivation, learning organization, flexible organization, the ability to change profit-sharing system, business expansion and job enrichment, autonomous work groups, small business units (Langbert, 2002:935) has entered the literature concepts. These concepts have been used to create a workforce with a high power of achievement.

The strategic approach to human resources management as academic way was introduced by Fombrun in the early 1980s. His book "Strategic Human Resources Management” was published in 1984 (Miller, 2006:99).

On the other hand, the relentless competition environment after 1980, the customer being the determining power, the establishment of customeroriented systems and the concept of continuous development (Langbert, 2000: 14), the discovery of the term "empowerment" in 1983 with concepts such as downsizing, rightsizing, reengineering, SWOT analysis with the concept of "competitive strategy" that has come to the fore since the beginning of the 1990s; preparation of organizational vision and mission statements; strategic plan implementation (Aktan, 2003:11), strategic 
talent management and organization to ensure maximum contribution to the development of the skills of the employees (Jensen and Spencer, 2004:31), and a lot of businesses and other organizational changes by increasing multinationalism of human factor and the strategic importance of human resources, "strategic management of human resources" has led to the establishment of the concept. As a result of the strategic management of human resources and the perception of human resources as a strategic resource, human resources management, which is defined as the critical factor of superiority in competition, has started to be seen as a "strategic business partner". This point of view is first described as a "full partner" (Kaynak et al, 2000:25) by providing human resources management with a voice in the formation of business policy and decisions, and later paved the way to having a seat at the top management table of organizations. Indeed, today, human resources managers are included in the top management of organizations, especially multinational corporations.

Strategic human resources management process in conjunction with corporate culture, committment, loyalty, coaching, mentoring, guidance, counseling, attitude-based training, managing diversity, change management (Brockbank, 2003:229), strategic talent management such as concepts and methods all has taken place in the literature. On the other hand, as a strategic partner, the role of the human resources manager was redefined in line with the organization's mission and strategy (Sheehan, 2005:193).

As a result, the 1990s were a period when human resources management supported and developed all the functions of the organization with the strategic concept of "human resources management" and demonstrated its decisive role in organizational performance and competitive superiority (Barutçugil, 2004:41-42). This is reflected in its position in the organization as a more competent human resource management than other functions. More importantly, strategic human resources management has also become an important instrument of the new economy (Werbel and DeMarie, 2005:247). This is because human resources are the main component of gaining a competitive advantage in the new economy as well. 


\section{Roles And Responsibilities of Contemporary Human Resources Management And Managers}

Today, the other name of human resources management is "change and development management "(Demirkaya, 2001:69). HRM with the dimension of change and development:

* Provides synergies between departments,

* Works for making internal communication in a healthy way, (Ersen, 1997: 44)

* Warns of behavior development,

* Establishes the education system and provides educational resources,

* Rewards employees' suggestions in accordance with the system,

* Works to ensure internal Justice,

* Contributes to the development of organizational structure,

* Places the awareness that all employees are customers of each other,

* Tries to ensure the placement of corporate culture (Fındıkçı, 2000: $18)$,

* Tries to uncover the potential of all employees,

* Compiles and combines all information about employees,

* Direct all employees to achieve the common goals of the organization,

*Establishes the necessary human resources systems for institutionalization.

Human resources management performs all these responsibilities in cooperation with other departments. Because it is not possible for human resources management to achieve success without the participation of other departments.

Human resources management coordinates the execution of all relevant affairs such as training within the organization, administrative affairs, industrial relations, personnel affairs etc. While performing these functions, it also establishes systems to ensure effective management of human resources. The systems that human resources management is responsible for establishing are: 
* Human resources planning system,

* Role definition, qualification and job analysis systems,

* Personnel recruitment, selection, placement and orientation system,

* Education system,

* Proposal and reward system,

* Performance evaluation and waging system,

* Career planning and organizational backup system,

* Industrial relations system.

All of these systems are necessary to establish and operate effectively in order for the organization to fulfill its mission and achieve its purpose. But installing these systems requires expertise. Therefore, today, the human resources manager's job specification is based on the fact that he/she has these specialized qualifications.

Looking at human resources management as one of the professions of the future, Özsoy also mentions that the human resources manager should use all of his employees effectively in line with organizational goals, taking into account all the factors. Moreover, determining how people work together more efficiently, managing change, and establishing effective roles in processes related to total quality (Özsoy, 2002:143-146). Indeed, there are important roles and responsibilities of human resources management at every stage, from the placement of total quality understanding to the acceptance of continuous development as a philosophy of life.

One of the new management approaches, reengineering (change engineering) such as Total Quality Management (TQM), brings new dimensions to the management and business world, changing the department of human resources management. Finally, within the scope of the phenomenon of productivity from caring values change (Hammer and Champy, 1994:59-68), human resources management reveals the necessity of change and look at events with new and different perspectives. The reengineering approach also imposes new roles and responsibilities on the human resources manager with the change obligation that it sets forth for human resources management. 
These new roles and responsibilities to the human resources manager also require new skills. In this sense, the human resources manager needs three types of skills:

* Human resources management skills,

* Business management skills,

* Change management skills.

Human resources management skills are already a mandatory criteria. In addition, business management skills and change management skills have been among the business specifications of human resources experts. A human resource manager to be just the expert of human resources practices are no longer enough, however, strategic planning, process technology, and information to be armed with the financial analysis; business management skills, data analysis, persuasion and change management skills, effective leadership are also required.

Depending on these skill criteria, human resources managers also climb to the top positions in the organizations. There are general manager-level titles in the public sector. In the private sector, titles such as coordinator and deputy general manager have started to become common. This trend is also directly proportional to the strategic importance of human resources. The integration of business strategies and human resources is only possible if human resources managers participate in the high-level decision process (Erdut, 2002:66). It can be said that the escalation of human resources managers to the top management of organizations and their participation in the strategic decision process will facilitate both the development of strategy and the formation of structural links with human resources.

The human resources research conducted by the Arthur Andersen human resources consultancy towards 2001 also reveals some findings that support this claim. According to some summary results of the study, human resources are now seen as an integral part of strategic management. Human resources managers are in the top management. Apart from the well-known areas of human resources responsibilities, creating corporate culture, corporate communication and developing the competencies of employees are the areas that should be given the most importance (Arthur Andersen Human Resources Consultancy, 2000: 13-238). 
Besides, how much the conditions of our country in many organizations, the human resources department is the only "fashion" started to be conducted without the scientific basis of many applications, and claimed that many practitioners didn't have sufficient knowledge (Ergin, 2002:199), Arthur Andersen Human Resources Consultancy research in our country shows that human resources management has changed dramatically the way the organizations look at.

\section{CHANGE IN INFORMATION SOCIETY AND HUMAN RESOURCES}

\section{Human in Information Society}

As a global paradox in economic, organizational and individual terms, globalization is changing both employees, organizations, and human resources management; at the same time, it offers new opportunities than ever before in human history (Naisbitt, 1994:216). Removing barriers to global information sharing along with information society processes affects organizations and business processes. The information economy, which is pronounced with the processes of the information society; information organization, information employee concepts as well as information processes have put an end to the thought of known management (Stewart, 1997:1-56). This also applies to the understanding of human resources management. Therefore, as revealed in Alvin Toffler's "Third Wave", "Future Shock", and "Power Shift", human resources management is on the eve of moving to different dimensions with the gains of the information society.

In fact, placing people at the centre of the information society, Peter Drucker (Beatty, 1998:227), the most important of the intellectual capital in the focus of successful business-minded, inquisitive, creative people (Duren, 2000: 100 ), to be the mainstay of the people on the eve of the 2000s and has become the most valuable resource of the knowledge economy (Stewart, 1997:37).

The fact of having intellectual capital, holding, developing and using it effectively, which is also the critical factor of superiority in competition, is associated with the effectiveness of human resources management. This has brought competence-based human resources management to the forefront in information societies, from recruitment-selection process to performance management and retention practices. 
Indeed, the information society has increased the information content of all businesses, thus making the educated, knowledgeable, creative person a symbol of the information society. Therefore, the wave of change faced by information society processes and human resources management is radically incomparable to the past. The concept of human being, which is the goal of human resources management at the beginning, has changed with the information society. Because the information society, where communication technologies carry information sharing to unimaginable dimensions, and where knowledge and skill preclude all kinds of resources, is built on knowledge worker and knowledgeable human resources. While the critical competitive factor for businesses, even nations, is still human resources, it has become the human resource that dominates, produces, and uses knowledge.

\section{Organizational Change of Human Resources Management in Information Society}

Information society processes have led to many changes in organizational context. The reasons for this are computerization, robotics and worldwide web opportunities, which have reached incredible dimensions in the information society, have brought many innovations to human resources management (Beagrie, 2004:26). Another reason for change is the increasing downsizing and outsourcing practices in the field of human resources (Davis, 2003:242). These facts have brought human resources management to new dimensions in individual and organizational terms.

The most tangible result of the new dimensions reached by human resources management along with information society processes has been the introduction of human resources management into a process of renewal. Within the scope of the renewal process, the organization of human resources, number of levels, number of employees, areas of expertise, duties-authorities and responsibilities are questioned and changed. In particular, the change affects the organizational dimensions of human resources management. The shrinking phenomenon necessitated by change refers to the decrease in human resources management levels. Human resources management's approach to specialization also has a major role in the reduction of levels. At the end of this impossible to avoid process, human resources management departments are expected to evolve from one level to a structure consisting of experts, each of whom is an 
expert in his / her field, but all of whom aim to develop human resources. As a matter of fact, this is essential for more effective human resources management.

Human resources management departments by re-structuring to maximize their efficiency have ceased to establish systems for making things better, or to be a place that prepares forms; in addition, they have become centers of change and development. For this reason, human resources professionals have turned into exchange experts in addition to their existing expertise.

Due to this transformation, department members have to rewrite their department's job descriptions, taking into account the changing department information, organization, duties, authorities and responsibilities. At the end of these processes, the aim is to create a new human resources department, which is equipped to be the partner of senior management, to be ambitious and expert in raising competitiveness.

The new department consists of experts who determine the corporate responsibility in line with the vision, mission, and values of the business and who produce information with a philosophy of continuous development. The information produced in the department will also have a value, a market. Considering that many human resources services are available from outsourcing today, it has become possible to share or sell the information produced in the specialized human resources department.

\section{Opening up Human Resources Management}

Depending on the specialization, human resources departments are opened out. In other words, for human resources departments, people have not only become business employees, but also customers have become the area of interest of the department.

Along with specialization and opening-up processes, professionals in human resources specialization were required having to come forward the leadership style, management intuition, foreign trade competition and financial knowledge, communication competency, and ability to work with their line managers (Selmer and Chiu, 2004:326). These are also key to effective business management. With these qualification criteria, it is revealed that human resources managers are candidates for business management. 
In fact, the human resources management and managers who want to embody their contribution to the business must be involved in every process that contributes to the success of the business, including purchasing, production, sales and after-sales services. In other words, human resources experts have to get out of their offices and get down to the field. Therefore, the common language of the human resources department is the strategy and its common goal is to increase the organization's competitiveness.

\section{Globalization of Human Resources Management}

The opportunities provided by the phenomenon of globalization and the information society unite nations and cultures as well as commercial integration. Therefore, as a global business instrument, human resources management has to understand the culture around the world, think globally and produce global business (Joy and Howes, 2003:168). Therefore, human resources have a duty to adapt people to competitive areas that are expanding due to globalization as a thought.

In addition, human resources management, with all these pioneering and strategic qualities, human knowledge and mastery of human resources, is also among the promising branches of science for the new economy where people are in focus. Indeed, new economy which covers information acquisition, processing, converting and distribution of information (Aktan, 2006)with its specialties as digitalization, research and development, globalization, and the radical changes in human resources are all associated with human resources management.

On the other hand, for multinational companies, the achievement of the objectives of the education funds to adapt to the social and cultural characteristics of the host countries (Gürün, 2001:185) also makes human resources management strategic in terms of educational and cultural cohesion. Indeed, human resources management, especially in multinational companies, management and human resources system to be applied as universal principles, rather than an approach that takes account of cultural differences by introducing cultural differences and local features of the disadvantage turns into an advantage.

In short, the importance attributed to human beings through information society processes enables the reinterpretation of human resources functions 
in all goods and services producing companies, strengthening respect for human rights, increasing freedoms starting from working life, and deepening democracy in all areas from family to society. In addition, it is preparing the ground for a more humane climate of the work life, for the improvement of the quality of the work life and for the improvement of the quality of life. With all these developments, human resources professionals are rapidly promoting to the top management of organizations.

\section{THE QUESTIONS THAT NEED TO BE ANSWERED BY HUMAN RESOURCES MANAGEMENT IN INFORMATION SOCIETY}

\section{Motivation}

It is human who makes the difference in the information society. What makes people different is their creativity and their contribution to the organization. Mobilizing the power to make this difference will continue to be a challenge in the information society as it has been in the past. In this sense, in addition to classical theories of motivation, there is a need for methods to motivate and stimulate the creativity and potential of the next generation of information employees. In the information society dominated by computers and robots, given the changing business and workplace concepts and the techniques of doing business, how to keep the golden collars, how to motivate them, how to measure performance, how to systematize wage and additional earnings, and what rewarding methods to apply are important problems, especially in the environments and spaces that are determined by themselves, will be a real new challenge facing the organizations.

\section{Education and Development}

Education and development is a must-have concept of the information society. The organization and educated employees should be in agreement on the strategic importance of education and continuous development. Theorists suggest lifelong education. This is also mandatory for organizations; but who will want it (Casey, 2003:632) is a question that needs to be answered. For this reason, education and development is an important problem in execution for whom, where, how and in what dimensions to do.

Considering the globalization of the resources to which information people will be provided, how to program education and development; how to 
neutralize cultural differences for human resources from different nations and regions, and melt them into the crucible of corporate culture; or how to make organizational gains by turning cultural differences into wealth, and how to substitute a function for career plans will continue to be problems for the organizations.

Despite this, web-based programs are heavily used to increase and expand human resources training and development programs. Websites created for this purpose provide extensive information and provide guidance to practitioners. They also facilitate adaptation to rapidly changing working life conditions and contribute to professional development (Kohl et al., 2004: 342).

\section{E-HRM and Outsourcing}

It is difficult to predict long-term effects of using software programs for many human resources functions, increasingly using of electronic human resources (E-HR) applications (Perrin, 2002:7), web-based testing and personnel selection (Wimbush, 2005:466), and the provision of critical functions through outsourcing.

Nowadays, because of increasingly more questioning of the value HR adds to the organization, human resources are faced to obligation of proving themselves. At the same time it is still a discussion point for the new structure of HRM in the future since web-based applications are increasingly used, the operational services and responsibilities are taken from HRM and transferred to the operational units, HRM is downsized in the organizations. On the other hand, it is difficult to predict how the information produced in the department that is expected to be specialized will be sold in global markets and what the individual or institutional outcome of this sale will be.

In the light of all these assessments, the most critical question is how the future of human resources management will be shaped; whether developments can destroy human resources management as other developments eliminated previous concepts. More clearly, will all these developments lead to a new management approach by destroying human resources management; or, by strengthening human resources further with its current practice, will open the way for Chief Executive Officer CEOs (Dagnon, 2003:281). This is already a very difficult question to answer. 


\section{CONCLUSION}

It is commonly said that human resources also exist on every ground where business, people and organization exist. In general, all employees (including managers, employers) in an organization make up human resources. However, it coincides with the period of the industrial revolution when organizations start considering human as an employee. Since the scientific management and ongoing periods, it is seen that classical personnel management takes place in organizations, from record-keeping to mid-level management.

The 1980s brought forth the concept of human resources management along with the phenomenon of change and transformation. Total quality processes have also contributed significantly to this. However, it is after the 1990s that the real breakthrough developments emerged. Human resources management is identified with change management because of the perception of change as an unchanging rule and the fundamental change in human perspective.

Today, the dimensions reached by the desire for change and institutionalization also shed light on the future of human resources management. On the one hand, human resources management, which is obliged to prove its contribution to the organization despite its downsizing, and on the other hand, organizations under pressure to shrink and become more effective due to relentless competitive conditions, meet in common interests. Organizations use every means to obtain the maximum benefit from human resources. This situation also imposes more strategic roles and responsibilities on human resources management, making it the most vital function for the organizational survival.

This importance brings human resources management, which is essentially an exciting and dynamic profession, to the forefront and brings human resources managers to the top management and decision mechanisms of organizations.

The information society processes that are taking place also raise many questions about the future of human resources management. Although these questions have not yet been answered, human resources management 
remains indispensable for organizations because of the importance given to human beings.

The predictions through all the developments show that human resources management, which is undergoing major changes from the agricultural society to the information society, will continue to be an important instrument of business management in the information society by changing to adapt, and by shrinking-to-become-more-effective.

\section{REFERENCES}

[1]Akdemir, A., (1999), İşletme Bilimine Giriş, Birlik Ofset Publishing, Eskisehir.

[2]Aktan, C. C., (2003), Değişim Çağında Yönetim, Sistem Publishing, Istanbul.

[3]Aktan, C. C., (2006), "Yeni Ekonomi”, Internet Adress: "http://www. canaktan.org/yeni-trendler/yeni-ekonomi/kavram.htm".

[4]Akyüz, Ö. F., (2001), Değişim Rüzgarında Stratejik İK Planlaması, Sistem Publishing, Istanbul

[5]Aldemir, C., Alpay A., ve Gönül B., (2001), İnsan Kaynakları Yönetimi, 4.Ed., İzmir.

[6]Andersen, A., (2000), 2001'e Doğru İnsan Kaynakları Araştırması, Sabah Publishing, Istanbul.

[7]Baransel, A., (1979), Çağdaş Yönetim Düşüncesinin Evrimi, Vol.1, 2nd Ed., Istanbul University Business Faculty Publishing, Istanbul.

[8]Barutçugil, İ., (2004), Stratejik İnsan Kaynakları Yönetimi, Kariyer Publishing, Istanbul.

[9]Bass, Bernard M., (1994), "Continuity and Change in the Evolution of Work and Human Resource Management”, Human Resource Management, 33(1), pp. 3-5

[10]Baysal, A. C., (1993), Çalışma Yaşamında İnsan, Business Faculty Press, Istanbul. 
[11]Beagrie, S., (2004), "Events that Changed Human Resources", Personnel Today, Nov.2, pp. 22-26.

[12]Beatty, J., (1998), Peter Drucker'e Göre Dünya, Translation: Osman Akınhay, Sistem Publishing, Istanbul.

[13]Bingöl, D., (1997), Personel Yönetimi, 3rd Ed., Beta Publishing, İstanbul.

[14]Brockbank, W., (2003), "Convergence of HR", in Marc Efron and et al (Ed.) Human Resources in the 21st Century, John Wiley and Sons Inc., NewJersey, p. 229.

[15]Casey, C., (2003), "The Learning Worker, Organizations and Democracy," International Journal of Lifelong Education, 22(6), pp.620634.

[16]Dagnon, James B., (2003), "HR as a Trusted Partner", in Marc Efron ant et al (Ed.) Human Resources in the 21 st Century, John Wiley and Sons Inc., NewJersey, p. 281.

[17]Davıs, K., (1988), İşletmede İnsan Davranışı, Translation: Kemal Tosun et al, 3rd Ed., Business Faculty Press, Istanbul.

[18]Davis, S. (2003), "Is This the End of HR?”, in Marc Efron and et al (Ed.) Human Resources in the 21st Century, John Wiley and Sons Inc., NewJersey, p. 242.

[19]Demirkaya, H., (2001), “Toplam Kaliteye Ulaşmada İnsan Kaynakları Yönetiminin Rolü”, Armed Forces Journal, 368, pp. 66-70.

[20]Demirkaya, H., (2004), Personel Yönetiminden İnsan Kaynakları Yönetimine, Internet Adress: www.insanvekalite.org.

[21]Düren, Z., (2000), 2000'li Yıllarda Yönetim, 1st Ed., Alfa Publishing, Istanbul.

[22]Erdut, T., (2002), İnsan Kaynakları Yönetimi ve Endüstri İlişkilerinde Değişim, "Türk Ağır Sanayi ve Hizmet Sektörü Kamu İşverenleri” Union Publishing, Izmir.

[23]Eren, E., (1991), Yönetim ve Organizasyon, Business Faculty Press, Istanbul. 
[24]Ergin, C., (2002), İnsan Kaynakları Yönetimi, Academyplus Publishing, Ankara.

[25]Ersen, H., (1997), Toplam Kalite ve İnsan Kaynakları Yönetimi İlişkisi, 2nd Ed., Alfa Publishing, Istanbul.

[26]Fındıkçı, İ., (2000), İnsan Kaynakları Yönetimi, 2nd Ed., Alfa Publishing, Istanbul.

[27]Gürün, F., (2001), Globalleşme ve Çokuluslu Şirketlerin İnsan Kaynakları Yönetimine Etkileri, Türk Tarih Kurumu (Turkish History Institiuion) Press, Ankara.

[28]Hammer, M., and James C., (1994), Değişim Mühendisliği, Translation: Sinem Gül, Sabah Publishing, Istanbul.

[29]N, Ed and Robert H S., (2004), "Transforming the HR Function", Utility Week, 21(17), p. 31.

[30]Joy, Robert J. and Paul H., (2003), "Globalization of HR", in Marc Efron and et al (Ed.) Human Resources in the 21st Century, John Wiley and Sons Inc., NewJersey, p. 168.

[31]Kaufman, B. E., (2001), "Human Resources and Industrial Relations Commanalities and Differences," Human Resource Management Review, 11(4), pp.339-374.

[32]Kaynak, T., Zeki A., İsmail A., Cavide U., Ömer S., Ahmet Cevat A., Oya Ö., Gönen D.,, Reha U., (2000), İnsan Kaynakları Yönetimi, 2nd Ed., Business Faculty Economy Institute Research and Support Foundation Press, Istanbul.

[33]Koçel, T., (1989), İşletme Yöneticiliği, Business Faculty Press, Istanbul.

[34]Kohl, J., Milton M., and Jacqueline M., (2004), "Human Resource Regulation ond Legal Issues: Web Sites for Instructional and Training Development," Journal of Education for Busienss, July/August , pp. 339343 .

[35]Köksal, M., (2005), İnsan Kaynakları Yönetimi, Kocaeli University Press, Kocaeli. 
[36]Langbert, M., (2000), “Human Resources Management and Deming's Continious mprovement Concept", Journal of Quality Managemenet, 5(1), pp. 85-101.

[37]Langbert, M., (2002), "Continuous Iprovement in the History of Human Resource Management”, Management Decision, 40(10), pp. 932937.

[38]Lee, M., and Valerie S., (1998), "Human Resource Development in the United Kingdom”, Human Resource Development Quarterly, 9(3), pp. 297-308.

[39]Miller, D., (2006), "Strategic Human Resource Management in Departman Stores: An Historical Perspective", Journal of Retailing and Consumer Services, 13(2), pp. 99-109.

[40]Naisbitt, J., (1994), Global Paradox, Translation: Sinem Gül, Sabah Publishing.

[41]Özkaplan, N., and Ahmet S., (2005), “ABD’de Çalışma Ekonomisi ve Endüstri İlişkileri Eğitim Üzerine”, “İş, Güç Endüstri İlişkileri ve İnsan Kaynakları" Journal, 7 (1), pp.1-11.

[42]Özsoy, O., (2002), Geleceğin Gözde Meslekleri, Acar Publishing, Istanbul.

[43]Palmer, M., and Winters K. T., (1993), İnsan Kaynakları, 1st Ed., Translation: Dogan Sahiner, Rota Publishing, Istanbul.

[44]Pannekoek, A., (2006), “Trade Unionism”, İnternet Adresi: http:// www.geocities. com/ Johngray/panunion.htm

[45]Perrin, T., (2002), "Online HR Services Continue to Grow”, CMA Management, 76(2), p.7.

[46]Selamoglu, A., (1998), “İnsan Kaynakları Yönetiminin Gelişimi”, A Gift to Prof.Dr. Metin Kutal, Mavi Publishing, Ankara.

[47]Selmer, J., and Randy C., (2004), "Required Human Resources Competencies in the Future: A Framework for Developing HR Executives in Hong Kong", Journal of World Business, 39, pp. 324-336. 
[48]Sheehan, C., (2005), “A Model for HRM Strategic Integration", Personnel Review, 34(2), pp. 192-209.

[49]Stewart, T. A., (1997), Entelektüel Sermaye, Translation: Nurettin Elhüseyni, MESS Publishing, Istanbul.

[50]Tosun, K., (1990), İsletme Yönetimi, 5th Ed., Business Faculty Press, Istanbul.

[51]TÜRKEL, Asuman Uluçınar (1998), İnsan Kaynaklarının Etkin Yönetimi, Türkmen Publishing, Istanbul.

[52] Ülgen, H., (1993), İsletmelerde Organizasyon İlkeleri ve Uygulamas1, 2nd Ed., Business Faculty Press, Istanbul.

[53]Werbel D. J., and Samuel M. D. M., (2005), "Aligning Strategic Human Resource Management and Person-Environment Fit," Human Resource Management Review, 15, pp. 247-262.

[54]W1mbush, J. C., (2005), "Spotlight on Human Resource Management", Business Horizons, 48(6), pp.463-467.

[55]Woods, R. H., (1997), Human Resource Management, Second Edition, Educational Insttitute of the American Hotel and Motel Assocation, Lansing, Michigan.

[56]Yozgat, O., (1992), İşletme Yönetimi, 8th Ed., Marmara Univesity "Nihad Sayar Eğitim Vakfı", Istanbul.

[57]Yüksel, Ö., (2000), İnsan Kaynakları Yönetimi, Gazi Publishing, Ankara. 